\title{
Analysis on the Problems in the Internal Control in Small and Medium-Sized Enterprises and Countermeasures
}

\author{
Yurong Gao \\ Shandong Women's University \\ Jinan, Shandong
}

\begin{abstract}
Small and medium-sized enterprises not only can optimize industrial structure and alleviate the pressure of employment, but also can better promote national economic development. However, with the complicated and diversified economic environment, there exist multiple risks in the internal control in small and medium-sized enterprises. Internal control plays a vital role in improving the management level of small and medium-sized enterprises. This paper analyzes the problems in the internal control in small and medium-sized enterprises and comes up with corresponding improvement measures from the aspects of internal environment, risk assessment, information systems and communication, control activity and supervision.
\end{abstract}

Keywords-small and medium-sized enterprises, internal control, problems, measures

\section{INTRODUCTION}

In today's world, small and medium-sized enterprises have become the main force in the economy of each region and country and account for more and more proportion in regional national economy. During the economic transition in our society, small and medium-sized enterprises account for more than $95 \%$ in total number of enterprises and its ultimate products and service value account for more than 50\% in GDP. But according to investigation, the life span for small and medium-sized enterprises is very short. The inadequate internal control in small and medium-sized enterprises causes many troubles for their development, thus making them develop very slowly.

\section{PROBLEMS IN THE INTERNAL CONTROL IN SMALL AND MEDIUM-SIZED ENTERPRISES}

\section{A. Weak foundation of internal control environment}

Sound control environment is the foundation of internal control. Small and medium-sized enterprises should establish and perfect governance structure, scientific and sound internal organizations, reasonable and effective division of power and responsibility, sound enterprises culture, policies about human resource, etc. to guarantee the execution of internal control, realized the goals of operating management and increase the objectives of future development for enterprises. However, due to historical and actual reasons, small and medium-sized enterprises in China lag behind in these aspects and management does not pay enough attention to internal control.
Most small and medium-sized enterprises are unitary property structure and most enterprises are established by one person or several persons. Daily management in such enterprises is directly controlled and managed by related people and right of management and ownership do not separate, which bring subjectivity into enterprise management and operating decision.[1] Lack of independent enterprise culture in small and medium-sized enterprises will make employees lack of shared management idea. The scale and limited number of employees are the reasons of unclear job responsibility. It is normal for an employee to be responsible for the work of other positions and lack professional training and education. Thus, low quality of staff leads to poor execution of internal control.

\section{B. Unsound risk evaluation system}

With the increasingly growing market economy, the risks small and medium-sized enterprises face are increasing. Scientific and reasonable risk evaluation can make enterprises enjoy sustained development in the future path and control existing risks within their own tolerate range. When facing high risks, some small and medium-sized enterprises formulate some specific system for internal control out of risk prevention, but most small and medium-sized enterprises with staff of low quality have weak awareness in risk management. In addition, they lack of professional management knowledge, risk evaluation institutions and perfect risk evaluation system, which cause insufficient effectiveness of risk control and management. Meanwhile, risk evaluation and response cannot be carried out in an effective manner, which also brings loss to enterprises.

\section{Poor communication within the organization}

It is indispensable to have smooth channels for information communication in any situations, especially in realization of effective internal control. Most small and medium-sized enterprises in our country pay more attention to top-down communication. Due to lack of information feedback mechanism, such communication is unsmooth and various illegal behaviors cannot be corrected timely, thus making such system perform practically no functions[3]. In addition, due to cost restriction, small and medium-sized enterprises generally do not consider to adopt information system management that causes low level of informatization, which not only has influence on information communication within enterprises and 
increases the communication difficulty among operating departments, but also causes ineffectiveness of internal control and greatly hinders the rapid development of small and medium-sized enterprises.

\section{Unsound and poor execution of the design of control activity}

Control activity is the key part of internal control. Its design and execution have certain impact on the role of internal control. From the investigation, the execution effect of small and medium-sized enterprises is not as good as we expect. Some enterprises only set up few internal control activities, which bring lots of loopholes and risks for them and hinders the execution of internal control. Many small and mediumsized enterprises adopt temporary orders and other informal ways to authorize and approve and they lack of execution in control activities. Therefore, it is hard to obtain ideal effect[5].

\section{E. Ineffective supervision to internal control}

The main function of internal control is to effectively control and manage various relative risks of operation, guarantee the authenticity and accuracy of financial accounting data in a proper manner and ensure the completeness of enterprises' assets. At present, ineffective supervision to internal control prevails in small and medium-sized enterprises in our country, which mainly reflects in the following aspects: on the one hand, influenced by cost factor and limited number of employees, small and medium-sized enterprises cannot strictly observe the requirements of internal control guidance to construct internal audit organization; on the other hand, even if internal audit organization is established, lack of independence for internal audit department and auditors will cause the failure of delivery of relatively objective evaluation when auditing internal control, which is not helpful for the improvement of the shortcomings in internal control and its role of supervision.

\section{STRENGTHENING AND IMPROVING MEASURES FOR INTERNAL CONTROL OF SMALL AND MEDIUM-SIZED ENTERPRISES}

\section{A. Improving internal control environment}

Internal control environment of enterprises is the cornerstone for the successful establishment of enterprises and execution of sound internal control. The improvement of internal control environment for small enterprises first of all start with senior management who must raise the awareness of internal control, set up and perfect the system of internal control and set a good example to execute internal control system. Small and medium-sized enterprises need to establish institutional framework with clear job responsibility and actively build enterprise culture with unique characteristics in order to better demonstrate their positive value, distinctive development vision, innovative enterprise spirit and honest and trustworthy management ideas and in the meantime create enterprise brand to facilitate health and sustainable development for small and medium-sized enterprises[2]. Enterprises should improve their policies of human resources and conduct sound management of human resources from recruitment, training and promotion to improve employees' quality.

\section{B. Building risk evaluation mechanism}

Perfect risk evaluation mechanism plays a vital role in effectively implementing internal control. Due to small scale and few excellent talents for these enterprises in our country, there is a certain lack of knowledge about risk evaluation. This requires small and medium-sized enterprises to employ professional risk assessors to solve this problem. In addition, the employees should have awareness of risk management, improve their ability in risk management and make correct judgment on risks[4]. Appropriate solutions should be adopted on the basis of identification and evaluation of risks enterprises face. In risk management, it should identify related responsible person. Small and medium-sized enterprises should build perfect relevant risk evaluation mechanism for each part of business activities and actively adopt measures to deal with enterprises' risks to control them in an affordable range and reduce losses.

\section{Regulating internal control activity}

Small and medium-sized enterprises should design control activities related to their business in accordance with their own characteristics to strengthen executive force and promote effective execution of control activities so as to give full play to internal control. First of all, enterprises should establish and perfect the system of internal control activity, standardized each business activities, separate duties from responsibilities and supervise each other. Secondly, the enthusiasm of employees who take part in internal control activities should be motivated from various aspects. Enterprises should make employees realize the importance of internal control activities and actively participate in by training, rewards and other means, thus making contribution to the improvement of the implementation of development strategy. Lastly, the execution effect of internal control activities can be included into performance appraisal system to promote all employees to effectively execute internal control system.

\section{Strengthening information exchange and communication}

According to the requirements of the system of information communication, a complete system needs to have latitudinal communication channels except top-down and down-top ones. It is the latitudinal communication that multiple small and medium-sized enterprises lack. Therefore, in practical work, small and medium-sized enterprises should attach more importance to latitudinal cooperation and coordination to realize the goal of sharing useful information among different departments. It should invest capital to improve informational level of enterprises and build informal communication channel to increase the efficiency of information communication. It has many channels to ensure the smooth communication: e-mail, online chat, online conference, on-site meeting and other many different channels which can meet different requirements. The combination of longitudinal and latitudinal information communication and exchange will guarantee the delivery of information timely and smoothly. All in all, promoting information communication and improving the degree of information utilization among different departments in enterprises are the important part to strengthen enterprises' internal control. 


\section{E. Intensifying the supervision of the execution of internal control in small and medium-sized enterprises}

The first thing to build highly independent internal audit organizations is to intensify the supervision of the execution of internal control in small and medium-sized enterprises. The existence of internal audit organizations won't bring great cost burden for small and medium-sized enterprises, but its effective supervision on internal control will bring higher earning of management for enterprises. Therefore, it is necessary for small and medium-sized enterprises to establish internal audit department to improve its independence, employ auditors with corresponding abilities to conduct daily and sustained supervision on the execution of internal control to urge enterprises to timely improve the system of internal control. What's more, the contents of internal audit cannot be restricted to the supervision on the standardization and legality of financial activities. It should enlarge its supervision to the whole process of each economic activities of enterprises and to the matters before and during the economic activities to improve its effectiveness. In addition, it should assign special person to execute internal control, combine internal control with performance assessment, build reward and punishment mechanism for the execution of internal control and strictly supervise the effective execution of internal control. Furthermore, it should introduce outsourcing mechanism of internal audit in which the third party will conduct objective supervision on each business of enterprises.

\section{CONCLUSION}

In brief, small and medium-sized enterprises should intensify their investment in the construction of internal control, optimize the control environment, establish and perfect risk evaluation system, strengthen information system and communication of enterprises and regulate internal control activities. In the meantime, it should conduct effective supervision on the execution of internal control to guarantee the effective operation of internal control and realize the goals of internal control, thus promoting health, sustained and stable development of enterprises.

\section{REFERENCES}

[1] Chen Yao, Research on Problems and Suggestions of Internal Control in Small and Medium-Sized Enterprises[J]. Times Finance, 2017. (02).

[2] Li Yong, Analysis on Internal Control Environment of Small and Medium-Sized Enterprises[J]. Communication of Finance and Accounting, 2015.(02)

[3] Xu Chongqin, Research on Problems and Suggestions of Internal Control in Small and Medium-Sized Enterprises[J]. China Economist, 2017,(12)

[4] Tao Ya, Research on the Internal Control in Small and Medium-Sized Enterprises Based on Risk Management[J]. Friends Accounting, 2015,(12).

[5] Liang Xiaochun, Study on the Shortcomings of Internal Control in Small and Medium-Sized Enterprises[J]. Accountant, 2017,(10). 